\title{
AN EMPIRICAL STUDY ON THE EFFECT OF ATTRACTIVENESS OF ECOTOURISM DESTINATION ON EXPERIENTIAL VALUE AND REVISIT INTENTION
}

\author{
CHIEN, M. C. \\ Department of Marine Leisure and Tourism, Taipei College of Maritime Technology \\ No.212, Sec.9, Yenping N. Rd. Shihlin, Taipei, Taiwan (11174), R.O.C \\ e-mail:mcchien@mail.tcmt.edu.tw \\ (Received 27 $7^{\text {th }}$ Aug 2016; accepted $17^{\text {th }}$ Nov 2016)
}

\begin{abstract}
When people are satisfied with the material life, they have abundant financial capability and time to stress on the leisure life so that the selection and frequency of recreation have been largely enhanced. A lot of touring spots attract people who live in urban jungles to visit the countryside with the ecological environment and historic and cultural monuments for appreciating landscapes and experiencing the local culture. Aiming at visitors to Maqaw National Park, a total of 400 questionnaire copies were distributed and 326 valid copies were returned with a response rate of $82 \%$. The research results indicated that 1 . The attractiveness of a destination presents significantly positive effects on the experiential value; 2 . The experiential value shows remarkably positive effects on the revisit intention; and 3. The attractiveness of destination reveals notably positive effects on the revisit intention. According to the results, suggestions are proposed for the reference of recreation planners, government departments, and successive researchers.
\end{abstract}

Keywords: interpersonal motivators, service superiority, aesthetic feeling, playfulness, consumers' return on investment

\section{Introduction}

After being satisfied with the material life, people have abundant financial capability and time to focus on their leisure life and participate in recreational activities. As the environment that is suitable for living and activities is limited, the selection and frequency of recreation are largely increased for the public. Public travels mainly involve in the "natural landscape appreciation", which is followed by the "cultural experiential activity". To cope with the requirements, a lot of touring spots would attract people who live in urban jungles to visit the countryside with the ecological environment and historic and cultural monuments for appreciating landscapes and experiencing the local culture. To develop tourism businesses, it is necessary to understand visitors' recreational behaviors and the factors in the attraction of recreation. During the consumption process, consumers would refer the perceived value to the purchase decision-making and the purchase of high-value products. A lot of researchers regard customers as emotional, rather than rational, who expect pleasant perception during the consumption process and emotional reactions during the consumption situation. Besides, using products in a leisure and funny process could help customers present high-value perception in order to enhance the purchase intention. Consumers would make purchase or repurchase decisions merely when they consider the advantage and meaning of a product or a service. A repurchase decision would result in the revisit intention, which refers to visitors being willing to visit the tourist destinations or other 
touring spots in the same country. As a result, the goal of this study is to understand and discuss the effect of attractiveness of ecotourism destinations on experiential value and revisit intention.

\section{Literature review}

\section{Attractiveness of destination}

Attractiveness, as the permanent power established in the same region, contains planned and developed places, such as cinemas, sports centers, theatres, and retail markets, and could provide consumers with places for education, interests, activity, and entertainment (de Ávila., 2011). In addition to the nature and human landscape, the attractiveness of an area could be created through human managements so as to combine and construct skills and strategies which could successfully induce consumers (Lemes et al., 2014). "Attractiveness" indicates that an object is attracted by the specific style of information from the subject to further appear the intention and actions for the satisfaction. Attractiveness shows the characteristics of recreation resources and special charm created by people, or the service and facilities which could satisfy consumer needs to enhance the interests in visit (Hultman et al., 2015). Accordingly, the attractiveness of an area not only is simply the nature and human resources of the area, but also includes the promotion and establishment of the area to build the attractiveness to appeal to population. For instance, by observing artificial landscape resources from consumer behaviors and the attractiveness of an area (Buckley et al., 2012), attractiveness acts as an important catalyst in visitors' participation motivation and the antecedent of participation motivation for the set-off effect (Ke, 2012). In short, attractiveness provides consumers with major motivation for action. Attractiveness is also a primary element in a tourism system allowing consumers to present the motivation so that an area without attractiveness could not permanently develop the tourism industry (Lo and Jim, 2015).

Referring to Chiu et al. (2014), the basic travel incentive is divided into four dimensions in this study.

(1) Interpersonal motivators, including visiting friends and relatives, making new friends in other places, and getting rid of work and family affairs.

(2) Physical motivators, containing rest, play, exercise, and therapy.

(3) Status and prestige motivators, covering exchange, inspection, conference, and personal research.

(4) Culture motivators, referring to understanding and appreciating the culture, custom, language, art, and religion in other countries.

\section{Experiential value}

Damodaran (2014) advocated that experiences are the economic product of services, starting from customers' consumption experiences, allowing consumers to be integrated into the situation through experience exhibition so as to create unforgettable experiences. In this case, the experiences of people would not be identical, because experiences exist in personal mind and they are internal and acquired through the participation in knowledge, emotion, and shape. Products, as a service, aimed to provide consumption experiences; however, consumers did not really want the product but 
rather the satisfactory experience, which was achieved through activity and between external economic activities and the internal world of a person. Ahmad (2015) indicated that recreation and tourism experience could be regarded as the subjective psychological state of a participant, and recreation experience was the comprehensive perception of all experience. Such an experience was acquired by visitors spending time on specific touring spots. Chaminuka et al. (2012) regarded value as a persistent belief and the preference of human actions which had the society or an individual prefer the existing purpose or certain behavior models, but not the opposite or relative purposes or behavior models. Husted et al. (2014) referred to "experiential value" as the cognition and relative preference for product attributes and service performance, which could enhance the value through interactions. However, an interaction, containing the subject-object relationship, might help or hinder consumers from achieving the goal. Bauer (2012) proposed that the experiential value was consumers' consumption value created after the experience. Experiential value was the cognition and relative preference for products and services; value could be promoted by an enterprise offering a product or a service by interacting with consumers; however, interactions could help or hinder the achievement of consumer goals (Ly and Bauer, 2014).

The classification of the experiential value proposed by Jung et al. (2015) is highly praised that it is adopted as the dimension in this study.

(1) Consumers' return on investment: Consumers' return on investment contains time investment, behavior, and financial investment, as well as psychological resources which could generate potential benefits.

(2) Service superiority: Service superiority is the internally passive reaction of consumers, coming from a consumer's praise of a market service (de Gusmão Pedrini et al., 2015).

(3) Aesthetic feeling: Aesthetic feeling refers to the directly perceived experience of consumers, including the senses of taste, touch, vision, and hearing of products, inner perception, enterprise environment, characteristics of aesthetic feeling, and psychological climate (Satyanarayana et al., 2012).

(4) Playfulness: The transaction of playfulness is the happiness of an inner reaction to induce inner perception with attractive activities and provide the need to temporarily escape from the reality (Reimer and Walter, 2013).

\section{Revisit intention}

Revisit intention, as the intention to recommend, broadly refers to visitors being willing to revisit the same destination or place, because of satisfactory travel experiences, and recommend the area or place to friends to form the word-of-mouth loyalty and suggestion. Revisit intention reveals the close concept to loyalty, referring to repurchase intention in the attitude and intention dimensions in loyalty theory. Some researchers also paid attention to the correlations between loyalty and revisit intention (Ahmed et al., 2015). Under such an idea, visitors' revisit shows great meaning on managing and knowing visitors' needs in tourism industry (Maulidya et al., 2014). Lu and Stepchenkova (2012) referred to a revisit as consumers being willing to visit the same destination or other touring spots in the same country that the convenience of visitors' previous "number of times", "transportation in destination", "travel experience", and "entertainment", the "economic" or "political factors" of "local price level" and "local hospitability", and visitors" "service satisfaction" and "recreation 
product" would affect visitors' revisit intention to the tourist destination or country. In this case, visitors would present higher revisit intention merely when perceiving better recreation experiences than expectation. Hanington and Martin (2012) discussed the visitor satisfaction with destination from "destination environment and facilities" and indicated that visitors presenting higher satisfaction with destination environment and facilities would enhance the revisit intention. Kang et al. (2012) mentioned that visitor behaviors contained the future behavioral intention, selection of touring spots, and the evaluation after travel. Evaluation after travel covered travel experience, perceived quality in the travel, perceived value in the travel process, and the overall satisfaction. Moreover, the future behavioral intention was referred to as the revisit intention and intention to recommend.

The revisit intention scale, which Cheung et al. (2014) used for measuring package tours, is used for measuring the revisit intention in this study.

\section{Research on attractiveness of destination and experiential value}

Husted et al. (2014) stated the positive and significant effect of visitors' attractiveness of destination on experiential quality and the indirect effect of perceived value and experiential quality on visitors' behavioral intention (Ramdas and Mohamed, 2014). It was clear that water activities in Penghu showed high attractiveness to visitors. According to visitors' travel experiences in Penghu, visitors showed favorable experiences in Penghu and the attractiveness and travel had visitors perceive the value (Reimer and Walter, 2013). Zhou et al. (2013) proposed the recreation experience theory and indicated that visitors involving in travels because of motivation would appear experiential behaviors and acquire expected satisfaction from the experience to further show the behavioral intention. Relevant research proved the remarkably positive correlation between travel motivation and experience (Shen, 2013), notably positive effects of participation motivation on satisfaction with the recreation experience (de Gusmão Pedrini et al., 2015), and positive recreation motivation, experiential perception, and experience satisfaction (Maulidya et al., 2014). The following hypothesis is therefore proposed in this study.

H1: Attractiveness of a destination shows significantly positive effects on the experiential value.

\section{Research on experiential value and revisit intention}

Visitors' recreation experiences would affect the revisit intention, and the higher experiential value results in the higher revisit intention. Samdin et al. (2013) considered that satisfactory experiential value did not simply present visitors' internal perception of recreation participation, but could effectively predict the revisit intention. Accordingly, it was primary to enhance visitors' experiential value in order to promote the revisit intention. Zsóka et al. (2013) discussed the tourist attractiveness, recreation experience, recreation satisfaction, and revisit intention to Tahu Township in Maioli and found out the positive correlations among tourist attractiveness, experiential value, satisfaction, and revisit intention. Regarding the prediction of visitors" "revisit intention", recreation satisfaction and the factors of hospitality service, product service, personnel service, and landscape present the biggest influence on the revisit intention. Accordingly, the following hypothesis is proposed in this study. 
$\mathrm{H} 2$ : Experiential value reveals remarkably positive effects on Revisit intention.

\section{Research on attractiveness of destination and revisit intention}

In the research on Kaohsiung International Container Arts Festival, Teksoz et al. (2012) discovered the notable correlation between the overall attractiveness and the revisit intention. Senyolo et al. (2014) combined product perception, interests, familiarity, and purchase in consumers' purchase process to study the effects of destination familiarity (having been to the place) on future intention that consumers' purchase decision-making (i.e., revisit) might be updated (Ahmed et al., 2015). Lu and Stepchenkova (2012) discussed the relationship among the perceived value, loyalty, satisfaction, and revisit intention after golfing experiences. The research result revealed that the perceived value, loyalty, and satisfaction could explain golfers' revisit intention. Cheung et al. (2014) investigated the causal relationship among motivation (divided into push and pull), satisfaction, and tourist attraction loyalty, where loyalty was divided into recommendation to others and revisit intention. Wu (2012) surveyed 282 visitors for the relationship among service quality, behavioral intention, and satisfaction in wildlife refuges. The results showed the significant effect of service quality and visitor satisfaction on the revisit intention. Consequently, the following hypothesis is proposed in this study.

H3: Attractiveness of destination presents notably positive effects on revisit intention.

\section{Sample and measurement indicator}

\section{Research sample and subject}

Visitors to Maqaw National Park, as the research samples, are distributed and collected the questionnaire on-site. A total of 400 questionnaire copies were distributed, and 326 valid copies are returned, with a response rate of $82 \%$. Maqaw National Park, also known as Qi-Lan Naitonal Park, was built as a national park in Taiwan. It covers Yuanyanghu Nature Reserve and Qi-Lan wildlife habitat, two nature conservation areas announced by Forestry Bureau. The cypress forest in Qi-Lan Mountain is located in the mountains with middle and high altitudes, where the high peaks, deep valleys, and sufficient rain and fog form the closed ecological environment so that rare gymnosperms are associated in the cypress forest, such as Arcto-Tertiary flora of Taxus chinensis, Taiwania cryptomerioides, Cunninghamia konishii Hayata, and Cephalotaxus wilsoniana Hayata. The long-term isolation and evolution form the endemic species in Taiwan; therefore, such a rare needle-leaved gymnosperm group evolves for tens of millions of years and even more than hundreds of million years that they could be "living fossil trees". The indicative status in the ecology evolution conforms to Article 8 of World Heritage nomination standards.

\section{Test of reliability and validity}

The so-called validity refers to a measuring tool being able to really measure the questions which researchers intend to measure. Validity is generally divided into the content validity, criterion-related validity, and the construct validity. Since the 
questions in this study referred to those proposed by domestic and international researchers, and a pretest is preceded after discussing with the tutor, the research questionnaire presents certain content validity. The dimensions of attractiveness of destination, experiential value, and revisit intention in this study are tested for the overall structural relationship with Linear Structural Relations Model, and the data are based on the correlational matrix of above observation variables. The analysis results with Linear Structural Relations Model revealed that the overall model fit achieves reasonable range that it shows favorable convergent validity and predictive validity.

To further understand the reliability and validity of the questionnaire, reliability and validity analyses were conducted in this study. According to Guilford (1965), the higher Cronbach's $\alpha$ presents the better reliability. Based on the standard, the Cronbach's $\alpha$ of the formal questionnaire in this study appears in 0.72 0.88, conforming to the reliability range.

\section{Analysis of empirical result}

The LISREL (linear structural relation) model combines the Factor Analysis and path analysis in traditional statistics and includes simultaneous equations in econometrics so that it could simultaneously calculate multi-factor, multi-causal paths. Regarding the evaluation of model fit, Bagozzi (1998) proposed to evaluate preliminary fit criteria, overall model fit, and fit of internal structure of model.

\section{Evaluation indicator of LISREL model}

According to Kerlinger (1986), item-to-total correlation coefficients could be used for testing the construct validity of questionnaire contents, i.e., judging the questionnaire content with item-to-total correlation coefficients calculated with reliability analysis. The item-to-total correlation coefficients of dimensions in this study are higher than 0.7 , revealing certain construct validity of this questionnaire.

The research data is organized in Table 1. In terms of the overall model fit, $\chi 2 / \mathrm{Df}=1.683$, smaller than the standard 3 , and $\mathrm{RMR}=0.003$ indicated that both $\chi^{2} / \mathrm{DF}$ and RMR are proper. Furthermore, the chi-square value is sensitive to the sample size so that it is not suitable for directly judging the fit. However, GFI $=0.974$ and AGFI=0.916 are higher than the standard 0.9 (the closer GFI and AGFI to 1, the better model fit) so that this model shows better goodness-of-fit index.

Table 1. Analysis of overall fit

\begin{tabular}{|c|c|c|c|}
\hline Evaluation & Parameter/evaluation criteria & Result & $\mathrm{t}$ \\
\hline \multirow{3}{*}{ Overall fit } & X2/Df & 1.683 \\
\cline { 2 - 3 } & GFI & 0.974 \\
\cline { 2 - 3 } & AGFI & 0.916 \\
\cline { 2 - 3 } & RMR & 0.003 \\
\hline
\end{tabular}

Note: * stands for $\mathrm{p}<0.05, * *$ for $\mathrm{p}<0.01, * * *$ for $\mathrm{p}<0.001$. 


\section{Analysis of preliminary fit criteria}

The research data is organized in Table 2. In regard to the preliminary fit criteria, the explanation of attractiveness of destination (interpersonal motivators, physical motivators, status and prestige motivators, and culture motivators) reached the significance level $(t>1.96, p<0.05)$; the explanation of experiential value (consumers' return on investment, service superiority, aesthetic feeling, and playfulness) reached the significance level $(\mathrm{t}>1.96, \mathrm{p}<0.05)$; moreover, the explanation of revisit intention reached the significance level $(t>1.96, \mathrm{p}<0.05)$. Apparently, the overall model in this study revealed favorable preliminary fit criteria.

Table 2. Analysis of preliminary fit criteria

\begin{tabular}{|c|c|c|c|c|}
\hline Evaluation & Parameter/ev & uation criteria & Result & $\mathrm{t}$ \\
\hline \multirow{9}{*}{$\begin{array}{c}\text { Preliminary } \\
\text { fit criteria }\end{array}$} & \multirow{4}{*}{$\begin{array}{l}\text { Attractiveness } \\
\text { of destination }\end{array}$} & $\begin{array}{c}\text { Interpersonal } \\
\text { motivators }\end{array}$ & 0.802 & $9.51 * *$ \\
\hline & & $\begin{array}{l}\text { Physical } \\
\text { motivators }\end{array}$ & 0.795 & $8.49 * *$ \\
\hline & & $\begin{array}{c}\text { Status and } \\
\text { prestige } \\
\text { motivators }\end{array}$ & 0.783 & $8.23 * *$ \\
\hline & & $\begin{array}{c}\text { Culture } \\
\text { motivators }\end{array}$ & 0.817 & $10.92 * *$ \\
\hline & \multirow{4}{*}{$\begin{array}{l}\text { Experiential } \\
\text { value }\end{array}$} & $\begin{array}{l}\text { Consumers } \\
\text { return on } \\
\text { investment }\end{array}$ & 0.823 & $11.48 * *$ \\
\hline & & $\begin{array}{c}\text { Service } \\
\text { superiority }\end{array}$ & 0.759 & $7.92 * *$ \\
\hline & & $\begin{array}{l}\text { Aesthetic } \\
\text { feeling }\end{array}$ & 0.831 & $13.23 * *$ \\
\hline & & Playfulness & 0.813 & $10.66^{* *}$ \\
\hline & Revisit intention & Revisit intention & 0.826 & $10.66^{* *}$ \\
\hline
\end{tabular}

Note: * stands for $\mathrm{p}<0.05, * *$ for $\mathrm{p}<0.01, * * *$ for $\mathrm{p}<0.001$.

\section{Analysis of internal fit}

The research data is organized in Table 3. Regarding the internal fit, the attractiveness of destination shows positive and significant correlations with the experiential value $(0.876, \mathrm{p}<0.01)$, the experiential value appears positive and remarkable correlations with revisit intention $(0.852, \mathrm{p}<0.01)$, and the attractiveness of destination shows positive notable correlations with revisit intention $(0.892, \mathrm{p}<0.01)$ so that hypotheses 1, 2, and 3 are supported. 
Table 3. Analysis of internal fit

\begin{tabular}{|c|c|c|c|c|}
\hline Evaluation & \multicolumn{2}{|c|}{ Parameter/evaluation criteria } & Result & $\mathrm{t}$ \\
\hline \multirow{3}{*}{ Internal fit } & \multicolumn{2}{|c|}{$\begin{array}{c}\text { Attractiveness of } \\
\text { destination } \rightarrow \text { experiential value }\end{array}$} & 0.876 & $21.69 * *$ \\
\hline & \multicolumn{2}{|c|}{$\begin{array}{c}\text { Experiential value } \rightarrow \text { Revisit } \\
\text { intention }\end{array}$} & 0.852 & $19.55 * *$ \\
\hline & \multicolumn{2}{|c|}{$\begin{array}{c}\text { Attractiveness of } \\
\text { destination } \rightarrow \text { Revisit intention }\end{array}$} & 0.892 & $26.43 * *$ \\
\hline $\begin{array}{l}\text { Research } \\
\text { hypothesis }\end{array}$ & Correlation & Empirical result & $\mathrm{P}$ & Result \\
\hline $\mathrm{H} 1$ & + & 0.876 & $\mathrm{P}<0.01$ & Supported \\
\hline $\mathrm{H} 2$ & + & 0.852 & $\mathrm{P}<0.01$ & Supported \\
\hline $\mathrm{H} 3$ & + & 0.892 & $\mathrm{P}<0.01$ & Supported \\
\hline
\end{tabular}

Note: * stands for $\mathrm{p}<0.05, * *$ for $\mathrm{p}<0.01, * * *$ for $\mathrm{p}<0.001$.

\section{Conclusion}

The research results indicated the positive and significant effect of the attractiveness of destination on the experiential value and the revisit intention. By analyzing the experiential value of ecotourism, visitors could best associate ecotourism to friendly services and enhance the ecotourism impression by enjoying the package tour. The higher attractiveness would enhance the experiential value. The experiential perception which visitors acquire in ecotourism would affect the revisit intention, and the higher experiential value would result in higher opportunities of visitors' revisit intention. The intention for a visitor to visit an ecotourism park is mainly to get his/her body and mind relaxed and the pressure released. The reason for appreciating natural environment presents the congestion and pressure of the people who live in urban environments and are in search of a temporary escape from their daily life. Visitors would show deeper attractiveness on the monuments, culture, and local specialties in ecotourism parks on the first visit. Those who have visited an ecotourism park for more than twice would pay attention to the participation of festivals and the appreciation of street shows due to their past experiences. It is also suitable for family tours and travels with friends so as to enhance the affection.

\section{Suggestion}

Aiming at the important research results and findings, practical suggestions are further proposed as follows.

1. The initial impression of visitors on ecotourism mainly depends on the introduction and therefore multiple marketing channels become important. However, it is the primary task to master and maintain the access for visitors acquiring information. For this reason, the relationship with marketing channels should be reinforced and a complete ecotourism introduction network should be constructed for a visitor to understand the overall situation of an ecotourism park before his/her arrival.

2. Ecotourism parks are suggested to well utilize the existing environment and resources, develop multiple and playful tours, and get closer to young consumers. 
Dynamic participation allows visitors to learn and grow up during the process and offers opportunities for ordinary people to understand ecotourism parks.

3. It is recommended to arrange some artists to perform in the open space so as to enhance the richness of programs, arrange interpreters in some touring spots, and plan a complete touring route. Recreation facilities should be regularly maintained so as to prevent interpretive panels from fading or rusting, which might result in shallow recreation experiences for visitors. The public sections that support the legalization of featured $\mathrm{B} \& \mathrm{~B}$ to connect $\mathrm{B} \& \mathrm{~B}$, restaurants, and touring spots could enhance the diversity of the tour and prolong the stay of visitors so as to deliver a deep impression on an ecotourism park.

\section{REFERENCE}

[1] Ahmad, A. (2015): Conservation of Island Biodiversity in Brunei Darussalam: The Role of Ecotourism in Environmental Education. - International Journal of Ecology \& Development 30: 51-63.

[2] Ahmed, A., Masud, M. M., Al-Amin, A. Q., Yahaya, S. R. B., Rahman, M., Akhtar, R. (2015): Exploring factors influencing farmers' willingness to pay (WTP) for a planned adaptation programme to address climatic issues in agricultural departments. Environmental Science and Pollution Research 22: 9494-9504.

[3] Bauer, I. (2012): Australian senior adventure travellers to Peru: Maximising older tourists' travel health experience. - Travel medicine and infectious disease 10(2): 59-68. doi: 10.1016/j.tmaid.2012.03.002

[4] Buckley, C., Hynes, S., Mechan, S. (2012): Supply of an ecosystem service-Farmers' willingness to adopt riparian buffer zones in agricultural catchments. - Environmental Science \& Policy 24: 101-109.

[5] Chaminuka, P., Groeneveld, R. A., Selomane, A. O., van Ierland, E. C. (2012): Tourist preferences for ecotourism in rural communities adjacent to Kruger National Park: A choice experiment approach. - Tourism Management 33: 168-176.

[6] Cheung, L. T. O., Fok, L., Fang, W. (2014): Understanding geopark visitors' preferences and willingness to pay for global geopark management and conservation. - Journal of Ecotourism 13: 35-51.

[7] Chiu, Y.-T. H.,.Lee, W.-I., Chen, T.-H. (2014): Environmentally responsible behavior in ecotourism: Antecedents and implications. - Tourism Management 40: 321-329.

[8] Damodaran, K. (2014): Willingness To Pay For Common Property Resources: A Study In Cuddalore District, Tamil Nadu. - Eduved International Journal of Interdisciplinary Research 1(7): 1-6.

[9] de Ávila, A. L. (2011): World Tourism Organization (UNWTO) Affiliate Members AM Reports. - Technology in Tourism 1: 10.

[10] de Gusmão Pedrini, A., Brotto, D. S., Ghilardi-Lopes, N. P., Lopes, M. C., Ferreira, L. P. (2015): Environmental education and ecotourism concepts in Marine Protected Area of Armação de Búzios, Rio de Janeiro, Brazil: reflections for the adoption of coastal ecotourism. - Revista Brasileira de Ecoturismo 8: 59-73.

[11] Guilford, J. P. (1965): Fundamental Statistics in Psychology and Education, 4th Ed. - NY: McGraw, Hill.

[12] Hanington, B., Martin, B. (2012): Universal methods of design: 100 ways to research complex problems, develop innovative ideas, and design effective solutions. - Rockport Publishers. 208 pp. 
[13] Hultman, M., Kazeminia, A., Ghasemi, V. (2015): Intention to visit and willingness to pay premium for ecotourism: The impact of attitude, materialism, and motivation. Journal of Business Research 68(9):1854-61. http://dx.doi.org/10.1016/j.jbusres.2015.01.013

[14] Husted, B. W., Russo, M. V., Meza, C. E. B., Tilleman, S. G. (2014): An exploratory study of environmental attitudes and the willingness to pay for environmental certification in Mexico. - Journal of Business Research 67: 891-899.

[15] Jung, W.J., Kim, T.H., Lee, S.Y. T. (2015): The Study on the Value of New \& Renewable Energy as a Future Alternative Energy Source in Korea. - Advanced Science and Technology Letters 86: 26-31.

[16] Kang, K.H., Stein, L., Heo, C.Y., Lee, S. (2012): Consumers' Willingness to Pay for Green Initiatives of the Hotel Industry. - International Journal of Hospitality Management 31(2): 564-572.

[17] Ke, L.(2012): The weakness and innovation of China eco-tourism. - Physics Procedia 25: 953-957.

[18] Lemes, M. T., Nunes, J. R., Nunes, P. A., Oliveira, S. S. (2014): Contribution of Ecotourism and Environmental Education at a resort located in the city of Nobres (MT, Brazil). - Revista Brasileira de Ecoturismo 7(1): 151-167.

[19] Lo, A. Y., Jim, C. Y. (2015): Protest response and willingness to pay for culturally significant urban trees: Implications for Contingent Valuation Method. - Ecological Economics 114: 58-66.

[20] Lu, W., Stepchenkova, S. (2012): Ecotourism experiences reported online: Classification of satisfaction attributes. - Tourism Management 33(3): 702-712.

[21] Ly, T. P., Bauer, T. (2014): Ecotourism in mainland Southeast Asia: Theory and practice. - Tourism, Leisure and Global Change 1: 20.

[22] Maulidya, F., Mudzakir, A., Sanjaya, Y. (2014): Case Study the Environmental Literacy of Fast Learner Middle School Students in Indonesia. - Environmental Education 3: 193-197.

[23] Ramdas, M., Mohamed, B. (2014): Impacts of Tourism on Environmental Attributes, Environmental Literacy and Willingness to Pay: A Conceptual and Theoretical Review. Procedia - Social and Behavioral Sciences 144: 378-391.

[24] Reimer, J. K., Walter, P. (2013): How do you know it when you see it? Community-based ecotourism in the Cardamom Mountains of southwestern Cambodia. Tourism Management 34: 122-132.

[25] Samdin, Z., Aziz, Y. A., Radam, A., Yacob, M. R. (2013): Sustainability Of Ecotourism Resources At Taman Negara National Park: Contingent Valuation Method. - International Journal of Business and Society 14: 235-244.

[26] Satyanarayana, B., Bhanderi, P., Debry, M., Maniatis, D., Foré, F., Badgie, D., Jammeh, K., Vanwing, T., Farcy, C., Koedam, N. (2012): A socio-ecological assessment aiming at improved forest resource management and sustainable ecotourism development in the mangroves of Tanbi Wetland National Park, The Gambia, West Africa. - Ambio 41: 513-526.

[27] Senyolo, G. M., Wale, E., Ortmann, G. F. (2014): Consumers' Willingness-To-Pay for Underutilized Vegetable Crops: The Case of African Leafy Vegetables in South Africa. J Hum Ecol 47(3): 219-227.

[28] Shen, H.L. (2013): Study on Non-use Values of Ecotourism Resources at Taroko National Park, Taiwan. - Journal of Anhui Agricultural Sciences 5: 80.

[29] Teksoz, G., Sahin, E., Tekkaya-Oztekin, C. (2012): Modeling Environmental Literacy of University Students. - Journal of Science Education and Technology 21: 157-166.

[30] Wu, B. (2012): The Promise and Challenge of Ecotourism. - Social Space 92: 106-109. 
[31] Zhou, Y., Buesching, C. D., Newman, C., Kaneko, Y., Xie, Z., Macdonald, D. W. (2013): Balancing the benefits of ecotourism and development: The effects of visitor trail-use on mammals in a Protected Area in rapidly developing China. - Biological Conservation 165: $18-24$.

[32] Zsóka, Á., Szerényi, Zs. M., Széchy, A., Kocsis, T. (2013): Greening due to environmental education? Environmental knowledge, attitudes, consumer behavior and everyday pro-environmental activities of Hungarian high school and university students. Journal of Cleaner Production 48: 126-138. 